\title{
Petrochronological and structural constraints on intra-oceanic subduction initiation from the metamorphic sole of the New Caledonia ophiolite
}

DERYA GÜRER ${ }^{1}$, BENEDICTE CENKI-TOK ${ }^{2,3}$, VASILEIOS CHATZARAS $^{2}$, FERNANDO CORFU ${ }^{4}$, JULIEN COLLOT ${ }^{5}$, PIERRE MAURIZOT ${ }^{5}$

${ }^{1}$ School of Earth and Environmental Sciences, University of Queensland, St. Lucia, Australia

${ }^{2}$ School of Geosciences, The University of Sydney, Sydney, Australia

${ }^{3}$ Géosciences Montpellier UMR5243, Université de Montpellier, CNRS, 34095 Montpellier cedex 5, France

${ }^{4}$ Department of Geosciences and Centre for Earth Evolution and Dynamics (CEED), University of Oslo Oslo, Norway

${ }^{5}$ Geological Survey of New Caledonia, DIMENC, Nouméa, New Caledonia

Subduction initiation is a critical stage of the Wilson cycle. Our understanding of the sequence of events that precede and postdate subduction initiation is limited, as only upper plate geological records are available in modern subduction zones, where subduction-related magmatism only allows to infer a minimum age for subduction initiation. In fossil systems, however, parts of both the upper and lower plate are often exposed, as supra-subduction zone ophiolites and their underlying metamorphic soles, respectively. The New Caledonia ophiolite formed in a supra-subduction zone setting in the vicinity of an active spreading centre. Its metamorphic sole is locally preserved beneath the ophiolite and represents the ancient subduction interface. Unravelling its tectonometamorphic record is essential to constraining the timing, sense and conditions of subduction initiation. We report petrochronologic constraints from laterally discontinous outcrops from three newly found and three previously known localities. U-Pb zircon ID-TIMS geochronology yields crystallization ages of $55.8 \pm 0.3,54.4 \pm 0.7$ and $56.7 \pm 0.3 \mathrm{Ma}$ in agreement, but with a narrower timespan compared to previously published data. We couple whole-rock geochemistry, mineral chemistry and thermodynamic modelling to constrain the P-T-t history. Microstructural data such as dominant deformation mechanisms, crystallographic preferred orientations, grain size distributions determined by EBSD allow to constrain the deformation processes and rheological behavior of the metamorphic sole during subduction infancy. 